\title{
IS PROPHETIC WITNESS THE APPROPRIATE MODE OF CHRISTIAN PARTICIPATION IN PUBLIC DISCOURSE IN THE NETHERLANDS?
}

\author{
Author: \\ Gerrit G. de Kruijf ${ }^{1,2}$
}

\section{Affiliations:}

${ }^{1}$ Protestant Theological

University, The

Netherlands

${ }^{2}$ Department of Systematic Theology and Christian

Ethics, University of

Pretoria, South Africa

Correspondence to:

Gerrit de Kruijf

email:

ggdekruijf@pthu.nl

\section{Postal address:}

Stationsstraat 21a, NL

2405BL, Alphen aan den

Rijn, The Netherlands

\section{Keywords:}

prophecy; democracy; theocracy; christianity; christian discourse

Dates:

Received: 23 Dec. 2009

Accepted: 04 July 2010

Published: 08 Oct. 2010

How to cite this article: De Kruijf, G.G., 2010, 'Is prophetic witness the appropriate mode of Christian participation in public discourse in the Netherlands?', HTS Teologiese Studies/ Theological Studies 66(1), Art. \#781, 2 pages. DOI: 10.4102/hts.v66i1.781

This article is available at:

http://www.hts.org.za

Note:

This article was initially presented as a paper at the conference on 'Prophetic witness: An appropriate mode of public discourse in democratic societies?' that was held at the University of Pretoria on 26-27 October 2009.

Prof. Dr G.G. de Kruijf is Professor Extraordinarius in the Department of Systematic Theology and Christian Ethics, Faculty of Theology, University of Pretoria.

(c) 2010. The Authors. Licensee: OpenJournals Publishing. This work is licensed under the Creative Commons Attribution License.

\section{ABSTRACT}

Dutch Protestantism is characterised by a hidden tension between a theocratic tradition and the endorsement of democracy. In this article it is argued that the idea of prophetic witness has its roots in the theocratic tradition, and that it is not compatible with the endorsement of democracy.

\section{INTRODUCTION}

\section{The church order of the Netherlands Reformed Church}

In 1952, the interchange of democracy and theocratic tradition resulted in the following formulation (showing a high level of self-consciousness) in the rules governing the Netherlands Reformed Church, which was valid until the unification with other churches in 2003:

The Church ... expecting the Kingdom of God continues ... the struggle in favour of the reformational character of state and people and addresses itself through its work on christianization to the government and the people in order to direct life according to the promises and commandments of God.

(Netherlands Reformed Church [n.d.])

It was particularly the influence of the theocratic theologian Arnold van Ruler that led to this formulation, but it was also approved by Barthians like Heiko Miskotte, who had in mind the experience of the need to be a confessing church during the Second World War. It implies the understanding of democracy as a lasting opportunity to strive for dominance of one's moral views. The church accomplished this task by delivering so called pulpit-messages, pastoral letters and 'assistance' until about 1990. Among these, the letters about nuclear arms attracted the most widespread attention.

In 1991, I criticised this position (de Kruijf 1991, 1994). Although allowed by the democratic system, it was not in accordance with the endorsement of democracy by the church. Even now I believe that many Christians in the Netherlands long for something like a restoration of the specific role of the church over against the State. And I consider the demand for prophetic witness a sign of this longing. Since 9-11 and the murder on Theo van Gogh, there is new debate in Holland about the role of religious argument in public life, and, indeed, Christians often seize the opportunity afforded by this new openness for religious reasoning in public debate to sound the trumpet again. My criticism of this position does not mean that I want the church to be silent on social issues. The social involvement of Christians and of the church is core-business, not only in diaconal work but also in discussion and public debate. But this should be distinguished from the effort to exert political influence on religious grounds, which was on the agenda of the Netherlands Reformed Church in the second half of the 20th century (the Dutch euthanasia law was the last example of this). And at least in the Netherlands, I see a strong connection between this political agenda and the call for 'prophetic witness'. This is what I am opposed to. Because I still think clarification on this point is necessary, I will give some of my arguments. At the end of this article I will comment on the formulation in which the Protestant Church in the Netherlands expressed its position in 2003.

\section{DEMOCRACY AND THE THEOCRATIC TRADITION}

With Reinhold Niebuhr and Karl Barth as its fathers, mainstream Protestant Christian ethics displays a preference for democratic order in politics and a conviction that the church should bear prophetic witness to the political community. To claim that the church should bear prophetic witness is to claim that the church can and should express the will of God for society as a whole and should do this in relation to specific, concrete political issues. Yet it is not certain that the endorsement of democracy is compatible with a prophetic understanding of the church. Democracy can, of course, be understood in two different ways, and it matters a great deal whether we understand it according to the Anglo-American model in which priority is accorded to the rights of individuals, or Rousseau's model with its concept of the general will. These models can also be distinguished as juridical versus philosophical, or as formal versus material, or as communal versus majoritarian. The category of prophecy is compatible with the majoritarian type (because the prophet claims to know what is good for the whole of society and is thus participating in the public struggle for establishing 'the truth'), but in Western political reality the liberal, juridical model is predominant. Therefore our question is: can one endorse liberal democracy while at the same time approaching it prophetically?

- The prophets in Israel presuppose openness on the side of king and people for their speech on the basis of the covenant. They share common grounds. The prophets put social reality in light of God's all-embracing reality. Prophets function within a theocratic ordering.

- After John the Baptist, the prophet is succeeded by the apostle. What the prophet presupposes now becomes the message of the apostle: the world belongs to Israel's God. This message divides the world. All peoples are called to believe this, but they do not share in the covenant in the way Israel does. Prophecy becomes a phenomenon within the Christian community. When Paul stands before kings, he does not speak as a prophet but as an apostle, proclaiming the Gospel 
and asking permission for his mission (prophets never asked permission, they immediately came to the social and international matters they wanted to discuss).

- Romans 13 is not about the relation between church and state, but about government as a gift of God for man's wellbeing: it is there to control violence.

- After Constantine, a culture arises in which the church becomes so dominant that it can act as if there is a theocratic situation. Church and state rule together. From this situation originate the traditional views on the relation between church and state. After the Reformation the principle remains the same, although interpreted less hierarchically and more complementarily. Democracy came up to make room for moral differences, both along the American and the European line. The separation of church and state characterises both, although this is of a more friendly nature in America than in Europe, because in Europe democracy was invented as a means to break the dominant position of the church. The churches (both Catholic and Protestant) were aware of that, of course, and they resisted democracy until the Second World War. Of course, the churches are not obliged to endorse democracy, they may insist on their theocratic privileges as long as church-members keep to the laws. (Is 'keep to the laws' correct? Shouldn't it be: 'obey the law'?) Nowadays, the churches have surrendered to the facts and as law-abiding institutions they are known for their loyalty to democracy. But the argument for that has never become very clear. And, at least in the Netherlands, they are always secretly trying to find a special position in relation to the government. It is in this context of marginalisation (from the 19th century onwards) that churches began to speak of their prophetic office (cf. Graf 1988:88-106)

- The theological basis for the recognition of democracy is, think, that faith is not compatible with coercion. The state has its identity in curbing violence by enforcing the laws. In a democracy, laws are enacted by parliament, representing the people and presupposing that the majority takes the moral differences in society into account (this is the meaning of the neutrality of the state; neutrality does not mean lack of identity.) Parliamentary debate is exercised within the language system of the tradition of the law. If the church fosters this argument for democracy, the implication is that she will normally not strive for a role as partner in a direct discussion with the government (except for the situation of a status confessionis). In most respects, she is not an organisation of interests (like trade unions for instance). The church is a class of her own, like a lamp that always spreads its light, but is more intensely noticed when the darkness deepens. As citizens her members will try to represent the light they see in political matters. All this is not to say that the church must foster democracy as the ideal form of political life. In accordance with Romans 13, she submits in principle to each form of state and assumes a fitting attitude.

- One of the peculiar characteristics of a democracy is that submission also implies active participation, the citizen not only being a subject, but also having active and passive rights. This creates the opportunity to participate in the debate on the question as to what we can reach agreement on in society, given many moral differences, while still respecting the conviction of others and remaining faithful to one's own beliefs. The church can certainly play an active part in shaping the opinions of its members on political issues, both on the institutional level and within the congregations. But as an institution, the church should not want to be a prophet in society.

\section{THE CHURCH ORDER OF THE PROTESTANT CHURCH IN THE NETHERLANDS}

Of course, all this implies a criticism of the church order which I quoted at the outset of my article. In 2003 the Protestant Church in the Netherlands opted for a different formulation:

In its celebrations, words and actions the church continually confesses Jesus Christ as the Lord and Saviour of the world and thus calls for renewal of life in culture, society and state. The church bears witness before people, powers and governments to God's promises and commandments and in doing so seeks a dialogue with other churches.

(Protestant Church in the Netherlands 2003:Art. I,6)

The main point in this new formulation is the fundamental identification of the church's role in society with its daily life: through its confessing life, the church fulfils its task in society. Special expressions are seen as extras (if necessary, if unavoidable). In the ordinances, this is elaborated as follows: the church supports the shaping of opinions in the congregations in societal issues, the church can deem it necessary to express itself on these issues, and the church can deliver a public 'witness'.

In light of my argument, these formulations are much better than the ones with which I started out. But of course they are open to different interpretations. There were letters about the law on euthanasia, as I mentioned, and about the war in Iraq, which were, in my opinion, too easily directed to the government. They also provoked expressions of disapproval within the church.

\section{CONCLUSION}

In a democratic society the church should not take on a prophetic role. The church must understand its task in respect to social ethics as the task of supporting and stimulating deliberation in the congregations. That is to say, the church should offer instruction in citizenship as well as the encouragement to participate in 'compromise-ethics' as a part of Christian ethics.

Toning down the political role of the church leaves room for just one exception: there may come a moment when faith in Jesus Christ does not allow submission to the direction of the actual policy of the democratic state. Then the Christian witness will coincide with a political choice of disobedience. Then politics becomes a matter of confessing, as it was in Barmen and Belhar. However, that lies in the sphere of ultima ratio. After the Second World War, people often tried to apply the experiences characteristic of the struggle with Nazism to more normal circumstances. They tried to institutionalise prophecy. They spoke sometimes of a continuous status confessionis. In the Netherlands and in Germany, this caused great tensions, especially in the debate on nuclear armament. According to the Dutch theologian Hendrikus Berkhof (1982:242-245), the 'no' towards the use of nuclear weapons ought to be expressed 'with prophetic force' and anyone who refuses that 'no' should be excommunicated. In response to this, Wolfgang Huber Huber (1985) suggested that even prophetic speech is not immune to criticism. In Huber's view, prophetic speech questions the legitimacy of political developments and rejects political decisions that sacrifice future possibilities of communal life to the dictates of present interests. Can we think of prophecy in such a methodical way? I would rather say: prophets rise, sometimes; their witness is born, not made. The church has to be liberated from the burden of the imperative to speak prophetically.

\section{REFERENCE}

Berkhof, H., 1982, 'Zwischen prophetie und weisheit'[Between prophecy and wisdown], EK 15, 242-245.

De Kruijf, G.G., 1991, 'The Christian in the Crowded Public Square: the Hidden Tension between Prophecy and Democracy', Annual of the Society of Christian Ethics, 21-42.

De Kruijf, G.G., 1994, Waakzaam en nuchter. Over christelijke ethiek in een democratie [Alert and sober. About Christian ethics in a democracy], Baarn, Ten Have.

Graf, F.W., 1988, 'Vom Munus Propheticum Christi zum prophetischen Wächteamt der Kirche?', ZEE 32, 88106.

Huber, W., 1985, 'Prophetische kritik und demokratischer Konens [Prophetic criticism and democratic consensus of opinion]', in T. Rendtorff (Hrsg.), Charisma und Institution, pp. 110-127, Gütersloher Verlagshaus, Gütersloh.

Netherlands Reformed Church, n.d., 'Governing rules', n.p.

Protestant Church in the Netherlands, 2003, 'The vocation of church and congretation', viewed n.d., from http://www. protestantchurch.nl/site/uploadedDocs/CHURCH_ORDER. pdf 